\title{
DEL
}

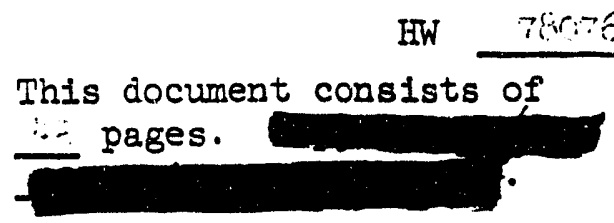

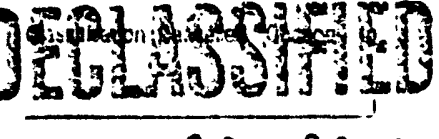

CHEMICAI PROCESSING DEPARTMENT

MONTIIY REPORT FCR

Ey Auseny $C G-P R-2$

$$
\therefore 7: \div 5 ;
$$

RM Iten 8-20-92

Complled By

HW- -78076

$\because 1$ Tang 9-23-92 OPERATION MANAGERS

TL Phillips 9-28-92

$$
9020,063
$$

\section{DE93 007071}

\section{HANFORD ATOMIC PRODUCTS OPERATION RICHLAND, WASHIINGTON}

Work performed under Contract No. AI ( $4, \ldots, \ldots)] 35 \%$ between the Atomic Energy Commission and General Electric Company.

\section{DISCLAIMER}

This report was prepared as an account of work sponsored by an agency of the United States Government. Neither the United States Government nor any agency thereof, nor any of their employees, makes any warranty, express or implied, or assumes any legal liability or responsibility for the accuracy, completeness, or usefulness of any information, apparatus, product, or process disclosed, or represents that its use would not infringe privately owned rights. Reference herein to any specific commercial product, process, or service by trade name, trademark, manufacturer, or otherwise does not necessarily constitute or imply its endorsement, recommendation, or favoring by the United States Government or any agency thereof. The views and opinions of authors expressed herein do not necessarily state or reflect those of the United States Government or any agency thereof.

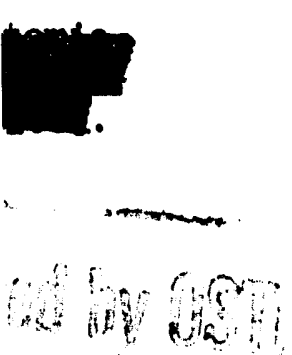

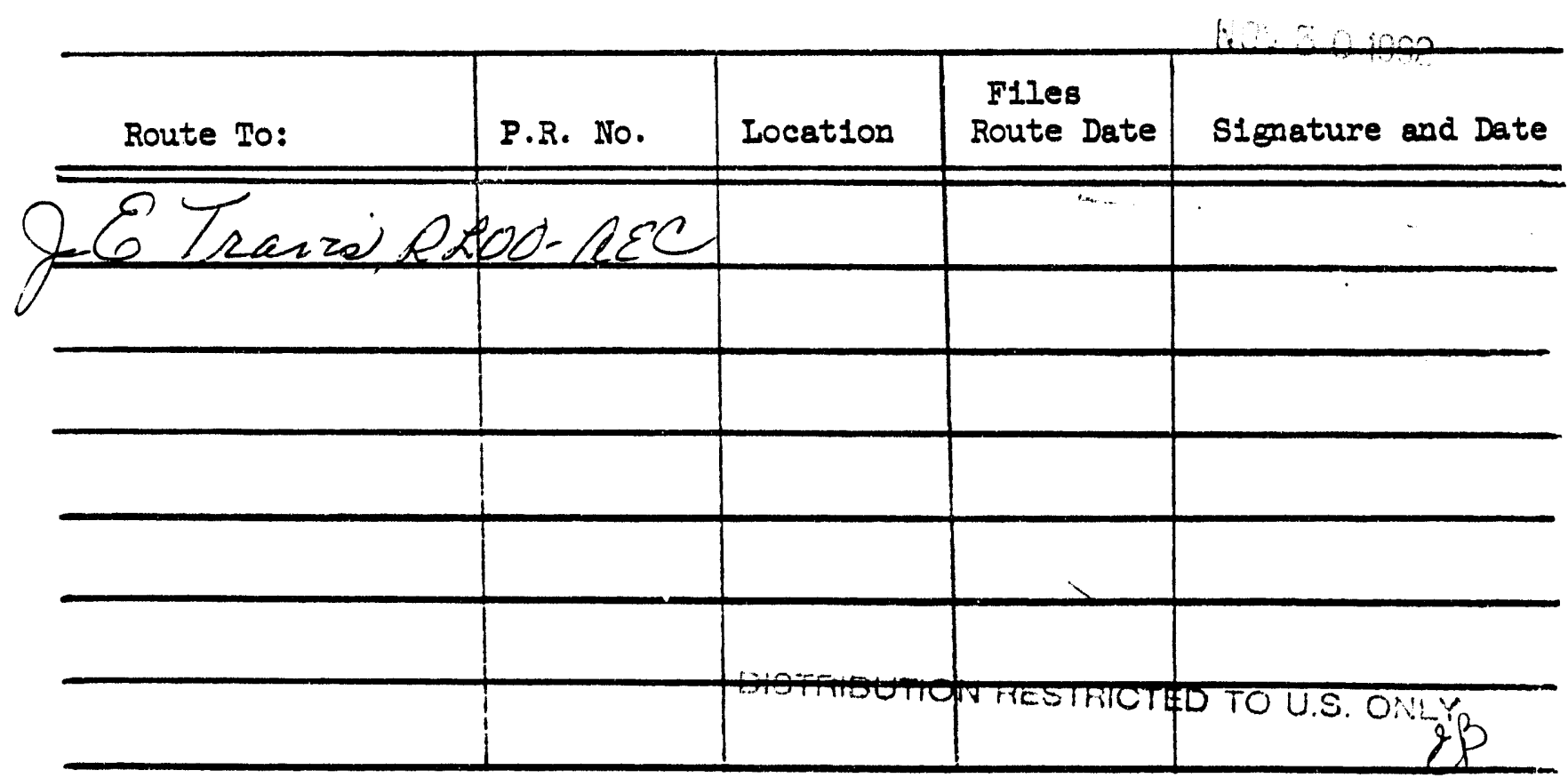


DISTRIBUTION

Coxy Number

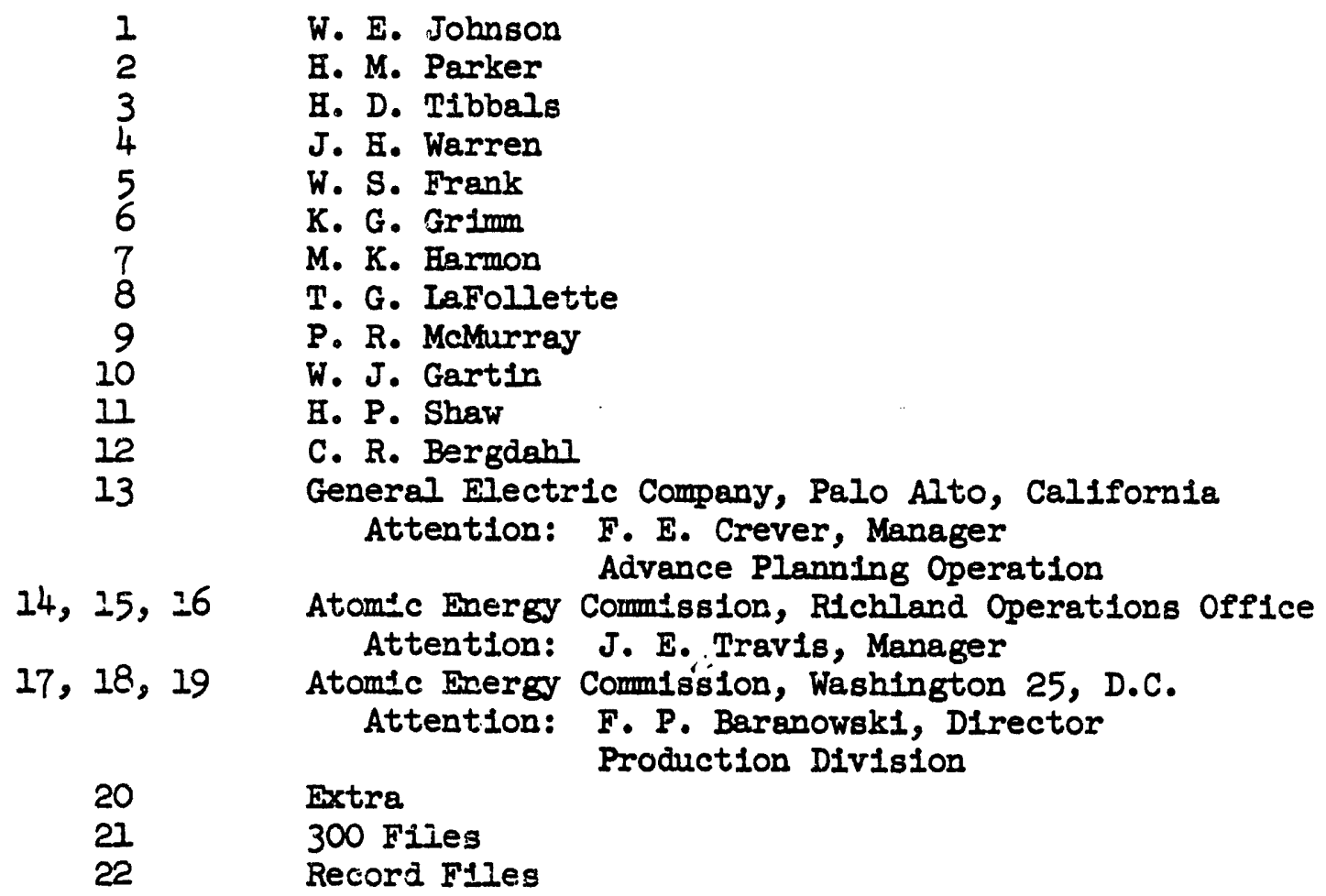


TAETEE OF CONTENTS

Distribution

Tabie of Cortent:s

Staf:

z. Simmary

II. Ack- ivemext:

A. Production Operation

B. Purex Operation

c. Fedox Operatıon

D. Wearcons Manufacturi=g Operation

E. Power and Crafts Operation

F. Fac1 Ittes Exgireering Operation

G. Research ara Exgineering Operation

․ Fiearozai Oporatior

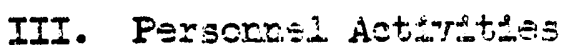

IV. Safety ard Security

V. Estorts Issied

VI. Fs?er:t Ënomary
$A=$ Timough A-3

E-1 Tirougt R-2

C-.. Tirough C-2

D-2 Truough D-3

E-2 Throigi E-2

F-2 Trough F-4

G-2 Thraigh $G-8$

E-I Tryouge $\mathrm{I}-3$

T-I Through :- 4

$\mathrm{K}-\mathrm{I}$

$I=-\operatorname{Trmoxz} I-3$

$M-2$ 
STAFF

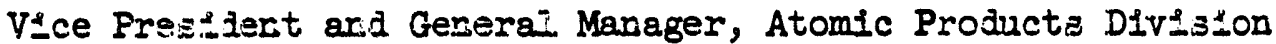

General Marager, Fanford Atcmla Products Operation

General Manager, Chemical Processing Department

Manager, Froduction

Manager, Furex

Masager, Rejox

Manager, Weapors Manufacturing

Manager, Power and Crafta Operation

Manager, Facilities Engineering

Manager, Research and Engineering

Manager, Finarce

Manager, Employee Felat_ons
I. R. Fink

W. E. Johnson

P. H. ReInker

J. H. Warren

F. R. McMurray

M. K. Harmon

W. T. Gartin

T. जิ. IaFoilette

H. P. Shair

W. S. Frank

K. G. Gr:mm

F. B. Er\&tton 
CHEMCCAI PROCESSING DEPARTMENP

MONIIII REFORT

JUNE, 1963

\section{SUMMAFY}

Production through June, as compared with the April 29, 1963 HAPO Production Forecast ( $\mathrm{WW}-77320$ ), Is summarized kelow:

\begin{tabular}{cc} 
Percent of Forecast Achieved \\
\hline \multirow{2}{*}{ Juce } & $\begin{array}{c}\text { F士scal Year } \\
\text { To Date }\end{array}$ \\
\cline { 2 - 2 } 119.5 & 100.8 \\
120.7 & 99.4 \\
106.6 & 98.5 \\
128.5 & 100.0 \\
52.9 & 98.3
\end{tabular}

June production of separated plutonium and separated uranium not only exceeded forecasted quantitIes but also established new record highs for both product3. The output of uranfum oxfde and plutonium metal buttons also exceeded forecasted quantities. The low production of fabsicated parts during June, as well as May, resulted from a reduction in delfvery requirements by the ABC.

Bxcept for a four-hour shutdown to repair a demineralized water line, the Purex plant operated continuously throughout June. All plutonium product met speciffcations; however, approximately.twenty tons of uranium product will require rework to reduce the plutionium content.

The HAFO II-1 cask, containing about 1000 thermal watts of strontium-90, was reieased for shipment on June 13.

Three sertes of strontfum recovery runs were completed in Purex head end equipment. The Iagt series was processed as the inftial strontium rareearth frection to be used for 3 Plant feed.

Following a survey by representatives of the Quality Assurance Agency from the Department of Military Appilcation's Albuquerque Office, a rating of "zatisfactory" was awarded to Eanford's Weapozz Qualsty Costrol program for Model 1807 parts. Upon compllance with geveral recommendations made by the group, Janford wi"? deIlver certified componezts not requiring reinspection at the custamer's plant.

The construction coctract for Froject CAC-964, "Iquapment Disposal-Furex," was awaried to Feter Kistet and Sons. Inc. on their Iow bid of $\$ 689,000$. The contractor arrives cz-3ite on June 24 and has 300 days to complete the work.

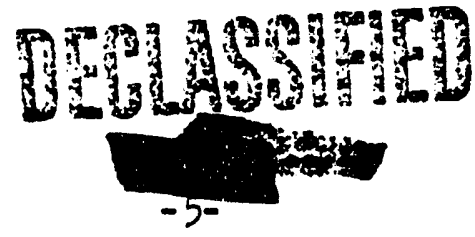




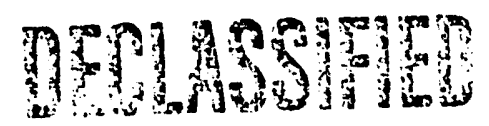

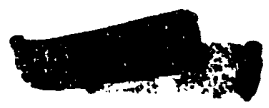

$\mathrm{HW}-78076$

An engineering study was completed for a special plutonium preparation facility, to be located in Room No. 179-B of the 234-5 Building. The study recommended that plans should proceed as rapidly as possible to develop the facility.

The rough draft portions of the final report on scope of the Hanford Isotope Plant (EIP) were completed in early June. Total operating and unit costs, for six additional unclassified production cases, were completed by June 18. A flowsheet and capital cost estimate were developed for Including CSREX fractionization of Durex Acid Waste in HIP.

Two disabling injuries were experienced in the Chemical Processing Department during June. The first occurred when an employee fell and incurred a chip fracture of the first lumbar vertebra. The second injury resulted from an employee's left index finger being pinched while connecting a trailer to a towing vehicle.

Pt. Linker

General Manager

Chemical Processing Department 


\section{CHEMICAI PROCESSING DEPARTMENT}

MONTHLY REPORT

JUNE 1963

\section{ACHIEVEMEENTS}

\section{A. PRODUCTION OPERATION}

1. Production Statistics

Fiscal Year

a. Percent of Forecast(1) Achieved

Separated plutonium nitrate

Separated uranium nitrate

Uranium oxide

Plutonium metal buttons

June

to Date

Fabricated parts

119.5

120.7

106.6

128.5

52.9

100.8

.99 .4

.98 .5

100.0

.98 .3

b.: Purex

June

May

Uranium nitrate produced (tons)

Average production rate during operation (T/D) 26.2

669.07

Total waste loss ( $\%)$

Plutonium

Uranium

On-line efficiency $(\%)$

0.33

0.22

98.43

30.8

0.34

0.36

76.9

c. $\underline{\text { Redox }}$

Uranium nitrate produced (tons)

Average production rate during operation (T/D)

Total waste loss ( $\%$ )

Plutonlum

Uranium

On-line efficiency (\%)

$131 \cdot 22$

6.9

35.03

8.2

0.34

0.24

64

0.29

0.29

18

d. Uranium Reduction (tons)

Normal $\mathrm{UO}_{3}$ loaded

Enriched $\mathrm{UO}_{3}$ loaded

Normal $\mathrm{UO}_{3}$ approved for shipment

Enriched $\mathrm{UO}_{3}$ approved for shipment

Normal $\mathrm{UO}_{3}$ shipped

Enriched $\mathrm{UO}_{3}$ shipped

Normal UNH backlog

100.10

494.03

100.33

Enriched UNH backlog

(1) HW-77320, HAPO PRODUCTION FORECAST, dated 4/29/63

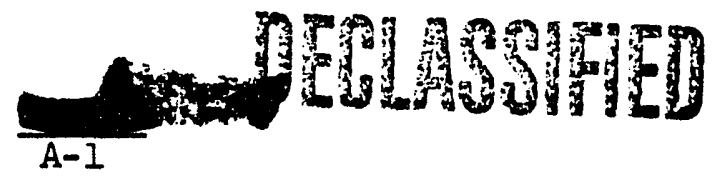


e. Plutonium Metal Processing

Reduction yleld ( $(\%)$

Product recovery output (Kgs)

Product recovery backlog (Kgs)

Waste disposal (grams)

f. Power

Raw water pumped (BTp)

Filtered water pumped (GPM)

Maximum steam generated (Ibs./hr.)

Average steam generated (Ibs./hr.)

Total steam generated (M Ibs.)

Coal consumed. (tons)

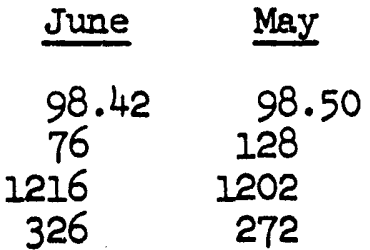

200-East 200-West

$\begin{array}{rr}12,194 & 5,027 \\ 1,292 & 1,170 \\ 220,000 & 110,000 \\ 206,000 & 92,000 \\ 146,274 & 55,962 \\ 7,387 & 2,871\end{array}$

June production of separated plutonlum and separated uranium not only exceeded forecasted quantities but also established new record highs for both products. The output of uranium axide and plutonlum metal buttons also exceeded forecasted quantities. The low production of fabricated parts during June, as well as May, resulted from a reduction in delivery requirements by the AEC.
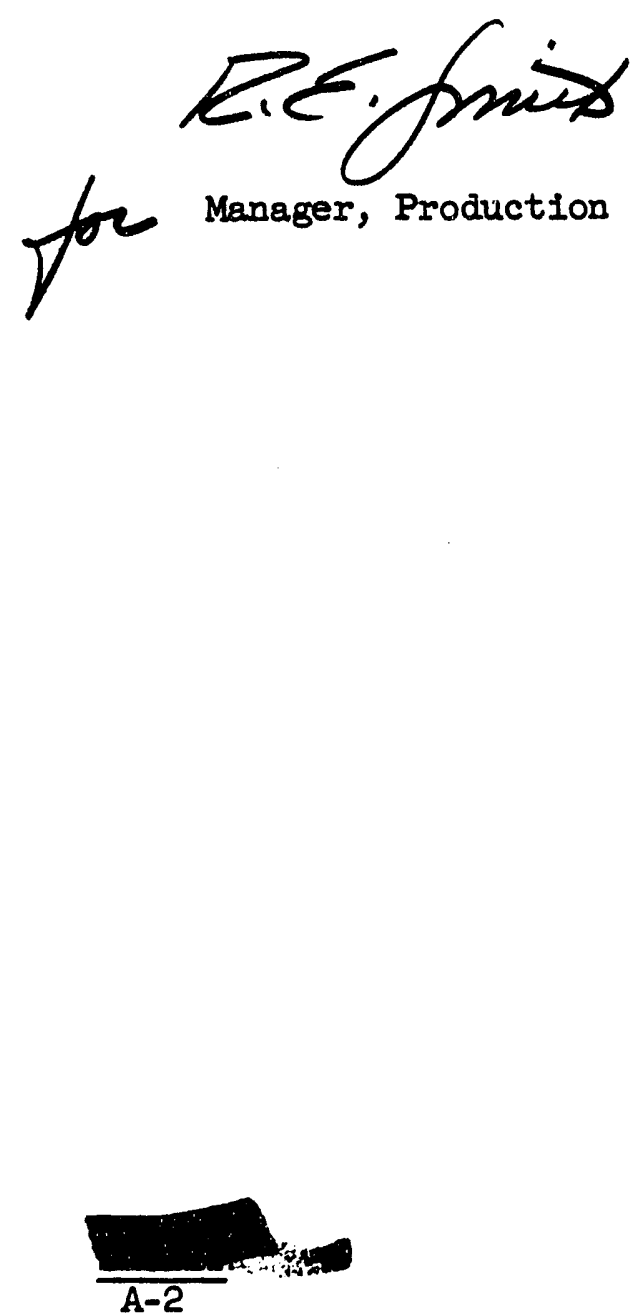


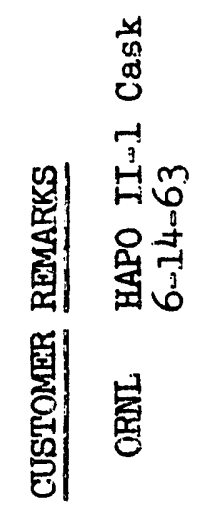

氛国影

氞甜

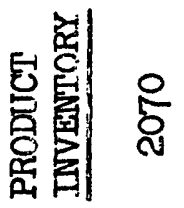
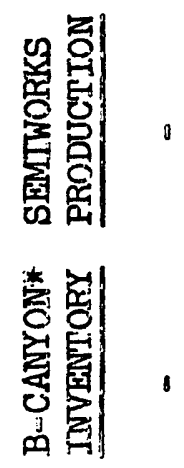

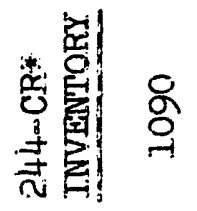

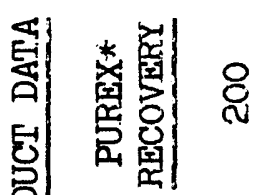

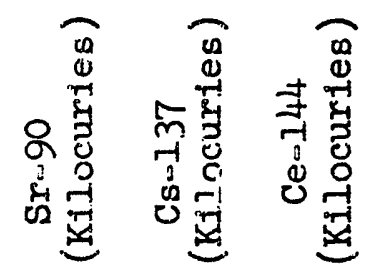

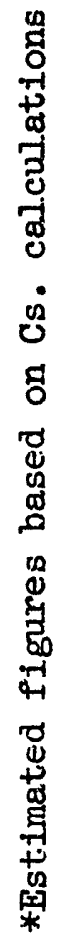




\section{CHEMICAL PROCESSING DEPARTMENT}

MONTHLY REPORT

JUNE, 1963

\section{ACHIEVEREMTSS (Continued)}

\section{E. PIREX OFERATION}

\section{Operating Continuity}

The Purex plant operated continuously throughout the month except for a four-hour shutdown to repair a demineralized water line.

All plutonium product met specification, but apprcximately twentyw ore tons of uranium produced will require rework through the final uranium cycle to remove above-limit plutonium impurity.

2. Frocessing Operation

The Neptuntum Purlfication Facility ( $Q$ Cell) continued to receive hot feed and two regular runs were successfully processed.

The HAPO II-I cask, loaded in May with $160 ; 000$ curies of Sro 90 , was shipped to ORLI on 6-13-63 while the HAPO I-B-I cask, loaded last December with 470,000 curies of Sr-90, remains in the shipping buffer awaiting AEC approval for shipment.

Three series of strontium recovery muns were completed in Furex bead end. The last series was processed as the initial strontiummare earth fracticn to be used for B Plant feed.

Strentium Semiworks completed the Research and Development mr stiarted In May for cerium separation from the rare earths. A second test min was completed which resulted in 88 percent exiraction of cerium and 90 percent of the promethium recovered.

Sludge testing with lance penetration was completed in $101 \mathrm{~A} A$ and 102-A waste storage tanks and confirmed the ablilty to penetrats the sludge with hot water at low pressures.

\section{Mechanfcal Expertence}

1. Falivirs of an outiet tee on a deminerglized water line caused a crash shutdown of the plant 6-30-63 for emergency repairs.

2. Fw? pump (acid waste feed to formaldehyde reacticn tank) fajiled and was replaced without a process shutdown.

3. The line from 003-CR vault to B Plant was hydrostatically tested and found in satisfactory condition.

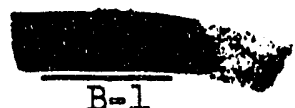


4. A modified 40" centrifuge was installed in E-4 spot for Purex head end processing.

5. Minor Construction completed welding plpe trench Iines in 22l-B and plant forces completed regasketing of assoclated cell jumpers.

6. Excessive inleakage in the $B$ Plant vessel vent system and instrument work on the Ring Balance recorders has delayed startup beyond the end of the month. Leak checking and corrective work have been started.

7. Inspection of the 40-ton holst cable on the west crane revealed damage and the cable was replaced.

8. The \#1 Purex canyon exhaust fan falled due to bearing trouble. The fan was completely overhauled and returned to service.

9. Fartition changes have been made in the control laboratory to accomodate the equipping of Hot Laboratory $\# 5$.

4. Rediation Experience

The total iodine 131 emission for the month was 9.32 curles. Maximim sevenuday emission was 3.62 curies. 
CHEMICAI PROCESSINU DEPARTMENT

MONTHLY REFORT

JUNE, 1963

II. ACHIEVEMENTS (Continued)

C. REDOX OFERATION

1. Operat ing Continuity

Effective June 3, the Redox plant went from a five to a seven-day-perweek operating schedule. Tiue additional manpower was obtained from the Weapons Manufacturing Operation and from Redox personnel on overtime as needed. Frocess difficulties limited operating time to approximately 65 per cent, and the anticipated production was not achieved despite the extra effort.

The Uranium Oxide plant operated at: satisfactory rates throughout the month, and the production and enipment of both depleted and enriched uranium were satisfacto:;

2. Processing Operations

a. Redox Processing

Processing of E-metal was started on 6-3-63 on a seven-day-perweek operating schedule. However, on 6-7-63 the D-14 backcycle feed pump falled, and when efforts to remove the pump from its base were unsuccessful, the alternate flow pattern used during the first quarter of 1963 was restored, by-passing D-14 once again. Processing of virgin feed was resumed on 6-11-63. Plant performance during the balance of the month was disrupted by otiex difficulties, however, and approximately seven more days were lost.

Neptinium stripping operations were resumed this month, and approximately 800 grams were being readied for shipment to the Furex plant at month end.

b. Traniva Oxide Processing

The prodiction and sinipment of both depleted and enriched uranium oxide met schedules for the month, despite crrtailments caissed by shortage of uranium feed and needed calciner repairs.

3. Mechanical Experience

a. Redox Plant

On 6-7-63 the D-14 backcycle feed pump failed, and all efforts to

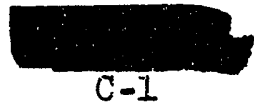


remove the pump from 1ts base were unsuccessful because two of the hold-down nuts could not be removed from the tank studs. The problem is being solved by a redesign that allows a new D-14 pump and the tube bundle to be ingtalled together in one of the ressel's heat exchanger pots.

b. Uranium Oxide Plant

The J-cell calciner was removed from service for three days during the IIrst part of the month to remove caked $U D_{3}$ from the agltator blade and the calciner trough.

The G-cell depleted uranium calciner was shut down for twelve hours on 6-12-63 to allow reflacement of the filter bags.

4. Waste Bandiling and Decontamination Operation

Equipment valued at approximately $\$ 52,000$ was recelved from the processing plants for decontamination, repalr, inspection or burial during the month. Equipment valued at approximately $\$ 19,000$ was returned to customers, representing a savings of approximately $\$ 11,000$ over the cost or new equipment.

\section{Radiat10a Experience}

- radioactive lodine emlsalon from the Redox plant showed an int. ease during the latter part of the month to a maximum of 0.9 curle par day. The rewedial actlons taken did not have the problem under complete control at month end.

The I-4 oxidizer became pressurlized on 6-27-63 during the boiling of metal feed solution when the vessel vent capacity was exceeded. An alarm system was Imediately installed on the H-4 pressure recorder to alert operating personnel to any suture pressurizations in the system. Also, Fac1ilties Engineering Operation started a study specifically of the B-4 problem, and will derlse a method for pressure rellef of all boll-up vessels in the cells.

\section{Analytical Experlence}

The two new 400-channel analyzers, ordered from the Rediat ion Instrument Development Laboratory, were recelved this month. Initial checking of the 1nstruments detected out-of-specification IInear1ty. Corrections were made by the vendor, and at wonth end, checking and evaluation of instrument performance was again under way.
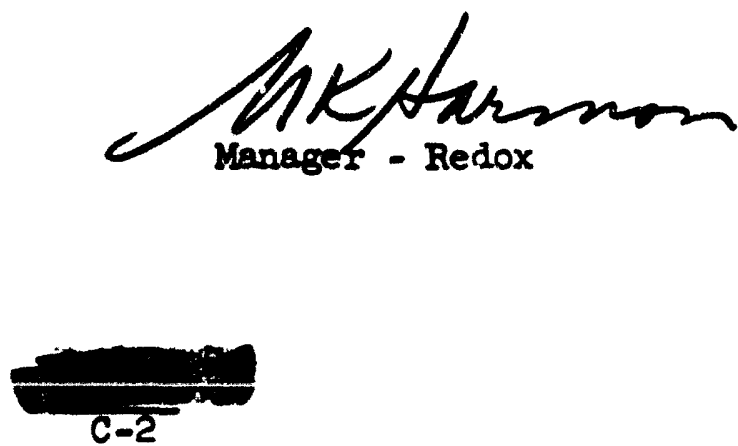
CHEMICAI PROCESSING DEPARTMENT

MONTHLY REPORT

JURE, 1963

II. ACHIEVEMENTS (ContInued)

D. WEAPONS MANUFACTURING OPERATION

1. Operating Continutty

The fabrication of Model 1807 plutonium weapon camponents continued to be Iimited as directed by the latest AEC interplant delivery schedule. Development efforts on Model 74-C were continued. The production of unfabricated plutonium exceeded schedule by about thirty percent. Recovery activities included limited dissolution of skull material and other high-purity scrap, as well as continued efforts to clean out se Recuplex stripper-concentrator. The incinerator remained out of suvice during the month.

2. Processing Operations

a. Plutonium Fabrication

Information on plutonium fabrication activities is presented in Document HW-78150 (Atamlc Weapon Data).

On June 10, 11 and 12, representatives of the Quality Assurance Agency of the Albuquerque Office of the Department of Military Application visited Hanford and conducted a survey of Weapons Quality Control activities related to Modei 1807 assemblies. A rating of "satisfactory" was awarded contingent lipon compliance with certain recomendations, making it possible for Hanford to deliver "certified" weapon components in the future.

\section{b. Plutonium Processing}

Button Iine feed supply was good and operating ratss were high during the morth. Interruptions resulted from bed compsction of the ion exchange columns as well as the usual mechanical problems.

The backlog of fabrication scrap was eliminated during the month. Diesolution of other high purity scrap materials is in progress.

Work continued on the removal of the hard folymer of plutonium from the J-26-A vessel (REcupie: stripper-concentrator). Another portion of the tank was clit away to permit access to the contents. At month end, approximately 10 kilograms of plutonium have been removed from this vessel, with an estimated two kilograms remain1ng.

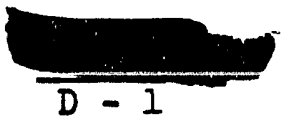




\section{b. Plutonium Processing (Continued)}

All previously used resin-fram the fon exchange unit has been cleaned and eliminated from the plutonium inventory.

3. Mechanical Performance

The machining equipment employed in the manufacture of the Model 1807- functioned with only normal maintenance required during the month. The high-frequency generator. for the 19-B induction furnace was successfully repaired in the 200-West Area motor shop.

The equipment for the production of Model 74-C functioned well w1th the principal difficulty involving the oxygen analyzer in the hood for the fifth Stokes furnace.

In Final Inspection, the million-volt $x$-ray equipment required extensive maintenance. It was necessary to employ the GE X-Ray Service Representative to diagnose a rectifier problem since access to the tube was required. Also the newly-installed Hadley density balance has been modified so that the use of correction factors is eliminated for regular operation.

Button Iine maintenance problems were Involved as usual with the filters, the vacuum system and the pumps. The recently fabricated stainless steel reactor vessel was installed in place of the easily damaged glass one. A new automatic, non-syphoning valve was installed between the feed tank and the reactor of the continuous processing unit.

\section{Radiation Experience}

Radiation and contamination control statistics reveal a sharp improvement in performance.

The single Radiation Occurrence which was experlenced Involved a Chemical Analyst whose face was sprayed by a dilute solution of plutonium nitrate fram a sample vial which had pressurized. All but a trace of the contamination was successfully removed by the end of the work day, and this remainder came off subsequently with the thin protective coating of plastic which had been applied. No plutonium deposition is expected to result from the incident.

The gamma radiation levels at Hood $7 \mathrm{~A}$ (feed and filtration for Ion exchange unit) was reduced 50 percent by the installation of lead glass shielding.

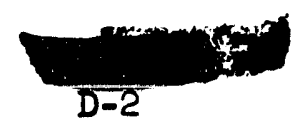


5. Analytical Experience

$$
\frac{\text { May }}{\text { "C" Line "Cune }}
$$

Numbers of Samples Recelved

Number of Determinations

Total Impurities, Buttons (Average)

Buttons Rejected

Pu240, Normal Buttons (by Neutron Count) $6.00 \%$

$$
3,122
$$

2,664

21,732

17,933

$\mathrm{Pu}^{240}$, Unclassified Buttons (by Neutron

Count) None

$\mathrm{ppm}$

$\begin{array}{cc}2,010 \mathrm{ppm} & 2,330 \mathrm{ppm} \\ 0.5 \% & 7.4 \%\end{array}$

$6.08 \%$ None

None None

A procedure for the determination of Americium has been set up in support of research programs, and for eventual use for the new reclamation facility (Project CAC-880).

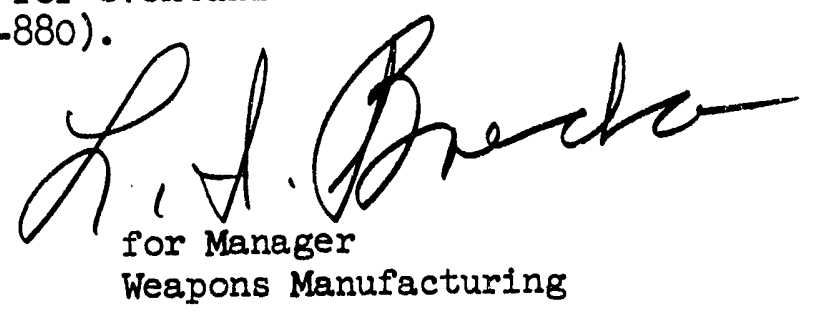




\section{(1)}

ज़W 78076

OHEMINAT PRDL ISSING IEFAFTMENT

MONTHLI REFISRT

\section{June $=963$}

II. ACEIETEMENTS (iontinued)

E. POWER ANI URATMS OPERATION

$\therefore \quad$ Operating Iontinuity

There were no outages of steam, water or electrical servises that arfectea continuity of operations of the proauction facilities during the period covered by this report.

2. Inspectior, Maintenance and Repair

Fabrization and instaliation of the EHood for the Weapons Manufacturing Operation's RMA Iine was rompleted. Installation of the various utilities and services required for the new hood was in progress at month's end.

A newiy designed insert cooling voi: was fabricated for immediate use in the D-14 Backcycle Concentrator at Redox. The new design incorporated a bracket for mounting a pumo which will be inserted through the center of the new coil. This was necessary due to difficulties encountered. $n$ attempting to remove the existing failed pump from its normal pos $i$ : on. The new coil was roized and assembled in accordance witsi $3 \mathrm{w}$ corrosion resistance weiding specifications.

A large shielded cask, identified as the "r-I Ioop Discharge Sask" was fabricated for research and engireering studies in the 100 Areas. The cask wi.l I transport irradiated fuel. elements between areas.

A titanium serew-type chlorinator was machined and ascembied for development studies by Hanford Laboratories: Pautonium ohemistry Iaboratory.

A spare $\mathrm{B} .4$ oxidizer coil was assembied and made reajy for the Redox facility。

Instaliation of appurtenances and associated equipment for the Weapons Manufa:turing Jperation's fifth Stokes fumsce was completed. Iniuded were:

1. The oxygen analyzer for controliing the nitrogen atmosphere in the hood.

2. The hydrauic electricai and instrumentation systems for controiling the air iock, rams and diverter, and

3. The eleatrical systems for operation of the conveyers.

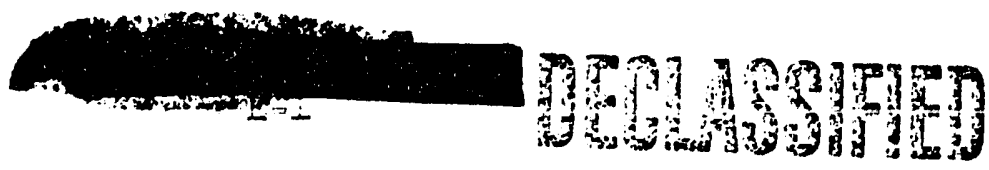


Thirty ceil-plpe jumpers, 18 for Redox, 12 for Furex, were fabricated during the month.

A smair hood was fabrizatec arj instaliea in weafons Msrufasturing Operation's inspection Iine for housing a Foskweli haraness tester.

A piutonium alioy pressing hood was instailed in Eanford Iaboratories 23i-Z faclitty. The hood had been fabricatea off-site and was tiedin to an existing hood by plant forces. Other work for $23.1-2$ inciuded fabrication of a large plutonium research hood, the installatlor of which is postponed pending a firm desision as to iocation.

Preiliminary tests were conducted on the feeding of potassium permangarate to the sanitary water system in 200 East Area. Trese tests were made at various feed rates. Final results are not known at this time.

Capact.ty flow tiests were conducted on the santtary water main fire hydrarts iocated around the 234-5 Builaing to determine if sanitarywater flow to this area was 1ncreased appreciabiy ss a result of the recent insialiation of a $3000-\mathrm{gpm}$ steam turbine pump in the $283 \mathrm{~m}$ Filter Piarit. It is evident from these tests that ine size to the 234.F Area is the restinting factor to increased water flow.

Activitiee of the department's ventilation baiance group performed in support of other departments included:

1. Preliminary work on air balance of the $1 C 5-N$ ventilation system.

2. Corcucting acceptance test procedure on revised rentilation units in the 190-KE ard KW Eullaings. (Project $1-383$.

3. Rebaiarce of the ventilatior systems in the $1706-\mathrm{KE}$ and $\mathrm{KEF}$ Buizangs. (Project Csi-97!.)

New presseri-wood tiie fioors (partile) were instalied in the administration builaing, 200 East Area (2704-E). The work was done to upgrade the existing substandara ficors to acseptabie standards and to obtain iower mairtenance costs.

Penovation of the entire seco::d floor of the 27--iJ Euilding, 200 West. Area, was ecmpleted to provide office spase for thirty afive Nuciear Material Opezation's empioyees. The work was performed by Minor

Construction forces. The spa:e was occupied byr the new tenants, June 29.

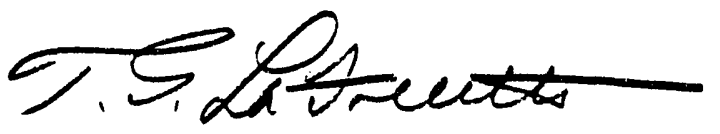

Manager

Power and irafts Operation

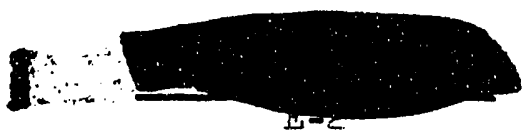


CHEMICAI PROCESSING DEPARTMENT

MONTHIY REPORT

JUNE, 1963

II. ACHIEVEMENTS (continued)

F. FACIITTIES ENGINVEERING OPERATION

1. Purex

a. Process Design Engineering

Purex Column Cartriage

New drawings were issued for the Purex HS and $2 \mathrm{E}$ column cartridges to correct the previously-failed cartridges. The new designs increase reliability of these units by improving structural rigidity.

b. Project Engineering

CAC-964 - Equipment Disposal - Purex

Construction bids from eight ( 8 ) bidders were opened on June 5. Bids ranged from $\$ 689,000$ to $\$ 894,500$, compared to a fair cost estimate of $\$ 845,000$. The Notice of Award and the Notice to Proceed were issued simultaneously to Peter Kiewit \& Sons, Incorporated, on June 10. The contractor has moved on-site and has 300 days to complete the work.

CAC-981 - Fission Product Packaging Facility - Purex

Directive No. HW-548, Rev. No. 1, dated June 13, changed project management responsibility from the Company to ROO-AEC. W. A. CAC-98I(1), dated June 27, authorized $\$ 16,500$ to the Compan. for technical guidance of design and other services. This is a reduction in General Electric authorization from the original $\$ 350,000$.

c. Manufacturing Engineering

UNH Transfer

The study of the methods and equipment used for the transfer of UNH solution from Purex to the $\mathrm{UO}_{3}$ Plant has been completed and presented to Purex management.

It was found that the present system is adequate from a capacity standpoint for present and proposed rates of production. Slight modification of equipment and operating pro-

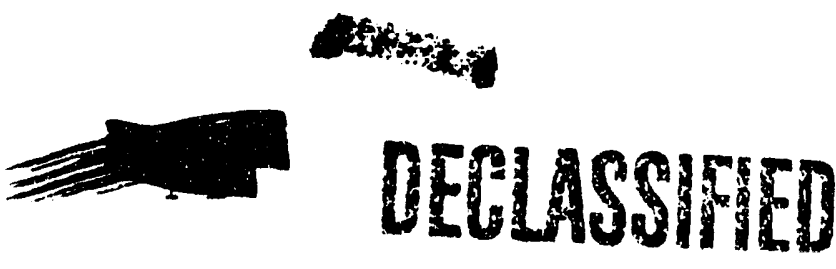


cEdure can yicidd a saving of $\$ 1 \equiv$, OSO per yiar based on present estimates of production. In iudition to eximining the present system, the possibi.ities of transfer by rail or pipeiine were examined.

2. $\quad \underline{R} \in \mathrm{d} e x$

a. Frcject Engineering

CAC-10I - Redoxw7

Direative No. AEC-22, dated June 4, authorized $\$ 110,000$ for design and construction. W.A. CAC-iOIi(1), dat sd June "'s authorized $\$ 3,100$ to the Company for technical. gutdance and other services. Design of the crib by Vitro Engineering Company was start: $=d$ on June 13 , and will require approximately four (4) weeks for zompletion.

\section{Weapons Manufacturing}

a. Process Design Engineering

Special Plutonium Preparation Facility Study

An engineering study on a special piutonium preparation facility for the 234-5 Building was completed and issued. As a result of this study, it was conoluded that Room No. 179-B is a better location for the facility than Room No. 148 . It was recommended that plans to develop $779 \circ B$ proseed as rapidly as possibie. The total cost for the individual giove box was estimated at $\$ 170,000$.

\section{RMA Fabrication Line}

Designs were completed and approved for rowcoutung the dry atmosphere glove box on the RMA sonveyor. This glove box will provide temporary facilities for develuping a part-stabiliza tion process.

An airnop grat $=d$ molid breaknout dsvi ze has besn designed, buiit, and tested. It is ready for instaliation in $H A$ wOOMB.

The finishing and $r e w$ trork gives $b=x$ HA. $40 F$, has $b \leq \in$ in stailed and is being connentej to existing servies. Ail de.w sign woris is compiet $=d$. Ail new towing and work gages de.. signed Ior the $7^{\prime}+$ Modei hare been built, and tise new inspestion optical comparator is on order.

RMC Fabrication Iine

Design sccpe is being prepared for use by Vitro in fexforming

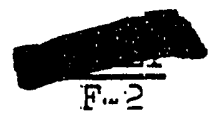


detall design. Tracings for detall design of the HC-30 Fabrication Oil Storage are ready for approval. Investigation of gasketing materials and methods for the air lock doors was continued.

\section{Incinerator}

The process incinerator is now being re-built. Detail design has been completed for re-routing the furnace flue gas line so the cold and hot streams join in a vertical section of pipe just prior to entering the off-gas scrubber. This change was made to eifinate the accumulation of solids in the horizontal pipe.

\section{Conveyor-Inspection Area}

The wearing of non-lubricated slats on the inspection area conveyor has caused the conveyor to move below the level of the sweep platform. This problem can be expected to extend into all conveyor systems; so plans are being made to set up a small section of conveyor for testing teflon tapes and Iubric cants.

\section{b. Project Engineering}

CGC-912 - Rev. \#4 - Waste Treatment Facility - "Z" Plant

A project proposal revision requesting an additional $\$ 158,000$ to improve the nuclear safety of the facility (approved locally on June 6), was sent to Washington AEC for approval on June 27. Vitro has been asked to provide an estimate of design cost for the work outlined in the proposal.

CGC-983 - Plutonium Ingoting \& Auxiliary Facilities - RMA Iine - 234-5 Building

Giove Box HA-2lI, ingoting facility, was placed in production on June 27. The project is 94.0 percent complete -25.0 percent ahead of schedule. Glove Box HA-22B, density determining facility, is 99.0 percent complete. Acceptance testing is scheduled for July 1 .

\section{CAC-987 - Metal Stabilization Facility - 234-5 Building}

Work Authority CAC-987(1), dated May 1, was received authorizing $\$ 205,000$ to the Company for procurement and technical guidance of the A-E. The specification for procurement of the 100,000 psi isostatic pressing system has been prepared and approved. 


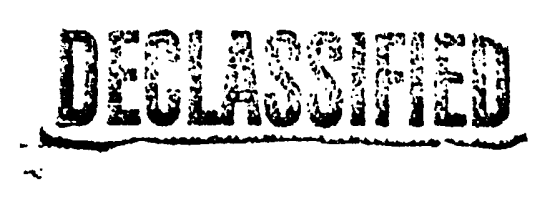

c. Manifacturing Engineering

\section{Power-roll Model}

The new IBM-orlented forms were deslgned for the processes ut1lized in manufacturing and inspecting the 74-C Model these are: (I) casting, (2) power-roll and machining, and (3) IInal inspection. The ingoting form has been designed and approved, and w1ll be used as soon as the ingoting hood is completed.

\section{General}

\section{a. Process Design Engineering}

\section{Waste Management Contatner Study}

Temperature profiles and capacity curves have been developed for altemate f1ssion product packages. Containers with bed thlcknesses greater than 4 to 6 inches will require internal fin arrangements due to low conductivity of zeolite resins.

\section{Fanford Isotope Plant}

The rough draft portions of the final report were completed the first week of June. Total operating and unit costs for six additional unclassifled production cases were completed by CPD FInancial on June 18. A flowsheet and capital cost estimate were developed for including CSREX fractionization of Purex Acld Waste in HIP.

The estimate is 14.3 million dollars for purification and packaging; however 29.0 million dollars is estimated when including fractionization. The cost increase results from the need to expand the diameter from approximately 105 to 175 feet and to add a second fioor AMU Gallery above the present operating gallery.

b. Project Englneering

Project Cost Information - as of 6/23/63:

$\begin{array}{lr}\text { Total Authorized Funds - } 14 \text { active projects } & \$ 3537000 \\ \text { Total cost-to-date } & 2736000 \\ \text { Commitments and Open Work Releases } & 273000 \\ \text { Unencumbered Balance } & 528000 \\ \text { Costs Charged to Above Projects }=5 / 19 \text { to } 6 / 23 & 182000\end{array}$

Projects dropped from active status during current period: Froject No. Authorlzed Funds Total Cost CGC-897 CAC-928 CGC-930 $\$ 1400000$ 88900 400000
71656

262000 
CHEMICAL PROCESSING DEPARTMEIT

MONTMLY REPORT

JUE, 1963

II. ACHIEVEMENTS (Continued)

G. RESEARCH AND ENGINEERING OPERATION

1. Purex Process Ergineering

(a) Feed Preparation

On June 3, a violent reaction occurred in the A3 dissolver when 50 per cent sodium hydroxide was added to a heel of bare uranium metal and a charge of aluminum-jacketed fuel elements. The reaction dislodged the charging chute cover and one and possibly two plugs in the off-gas system. After replacing the cover and plugs, the dissolver system was visually inspected for damage, checked for water leaks and returned to service with no evidence of major damage. There was no spread of contamination into the operating areas or outside the building. Iaboratory dissolving studies and engineering pressure-impulse calculations by Hanford Laboratories personnel are underway to evaluate relative effects of pressurization by rapid gas evolution or an actual explosive reaction.

\section{(b) Solvent Fxtraction}

In-plant testing of hydrazine vice ferrous sulfamate as a plutonium reductant in the feed to the Second Uranium Cycle was suspended due to a shortage of hydrazine. Test results thus far indicate that:

(1) The plutonium content of the uranium product can be reduced to the analytical detection limit ( $1 \mathrm{ppb}$ ) by concurrent addition of hydrazine to the ICU Concentrator and ferrolus sulfamate to the $2 \mathrm{DF}$.

(2) Hydrazine alone at concentrations up to $0.05 \mathrm{M}$ results in plutonium concentrations above specifications in the iranium product.

(3) Second Uranium Cycle decontamination periormance appiats to decrease as the concentrations of hydrazine in the $2 \mathrm{DF}$ approach 0.05 M.

(c) Product Treatment

The second neptunium purification run was successfully completed in the new ion exche ge unit. The final product was well within

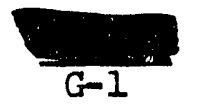


all shipping specifications. Typical decontamination and waste loss performance data are as follows:

Decontamination Factor

Waste Ioss Per Cent of Feed

$\begin{array}{cr}\text { Zrivb } & 1300 \\ \mathrm{Ru} & 630 \\ \mathrm{U} & 50 \\ \mathrm{Pu} & \text { Nondetectable in Feed } \\ \mathrm{TMI} & 60\end{array}$

Loading Step $\quad 0.91$

Washes 0.21

Elution Forecut 2.2

(d) Water Treatment

Treatment of the raw water with 1 ppm potassium permanganate before normal flocculation and demineralization was tested in the Water Treatment Plant. Although analytical data are not yet available, visual observations of the pink color indicated the permanganate was quickly destroyed by organics in the water. The system is intended to serve as a backup to permanganate treatment of the solvent for removal of organic materials affecting process performance in the Second Uranium Cycle.

\section{(e) Acid Recovery}

Variables affecting fission product entrainment in the high-level waste concentrator were studied with the following conclusions.

(1) A flow of water to the second tray in the tower reduced entrainment by a factor of two.

(2) A 15 per cent reduction in boilup rate did not affect the amount of entrainment.

(3) Addition of $5 \mathrm{ppm}$ of antifoam to the feed to the concentrator did not improve deentrainment.

(f) Fission Products

Plant-scale studies of ways to separate cerium from the rare santh 3 by oxidizing cerium to $\mathrm{Ce}-I V$ and batch extracting with di (e-etiryinexyl) phosphoric acid (D2EHPA) were completed. The most promising oxidant was sodium bismuthate. Results of these studies ean be silmorized as follows:

\begin{tabular}{|c|c|c|c|}
\hline Dxidant & Aqueous Concentrat:on & Contadet ine & 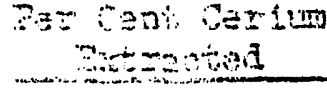 \\
\hline $\begin{array}{c}\mathrm{NaSiO}_{3} \\
\mathrm{PbO}_{2}-\mathrm{KMnO}_{4}\end{array}$ & $\begin{array}{l}0.050 \\
0.075 \\
0.095 \\
0.04-0.04\end{array}$ & $\begin{array}{l}30 \\
75 \\
30 \\
40\end{array}$ & $\begin{array}{l}50 \\
80 \\
95 \\
75\end{array}$ \\
\hline
\end{tabular}

The cerium was easily stripped from the organic with $1.5 \mathrm{M}$ nitric acid and $0.2 \mathrm{M}$ hydrogen peroxide. 


\section{Redox Process Engineering}

a. Plutonium Anion Exchange

The I-18 Plutonium AnIon Exchange Contactor was operated for most of the report period usirg a pulser to purp the resin. The pulser was developed by Chemical Development, Hanford Laboratories. It consisted of a diaphragm operated Teflon bellows pump attached to a tee in the contactor loop with ball checks above and below the tee to direct resin movement around the 100p. By using the pulser to move the resin rather than pushwater, it is possible to reduce the amount of slipwater and thus acileve more column volumes of scrub with the same flow rate of scmb solution. A decontamination factor across the contactor as high as an arithmetic 6000 was observed. One problem encountered was that of air in-leakage collecting in the bellows which cushioned the pumping cperation. The air had to be bled off frequently in order to keep the resin moving.

b. Iodine Retention

A new activated carbon filter was installea downstream from the sandfilter on 5-28-63. The radioactive iodine retention of this filter was less than 50 per cent instead of the anticipated 95 per cent (based upon sand-filter test data). This filter is one inch thick, contains 10 to 14 mesh coconut base activated carbon, has a cross section of 450 square feet, and handles a gas flow of approximately 33,000 cublc feet per minute. The building ventilation system and all of the process vessel vent systems except the dissolvers are handied by this filter. 
HW -78076

\section{Plutonium Process Engineering Operation -}

a. Button Iine

The yield across the supematant anion exchange unit was 99 per cent. Continued use of this facility has demonstrated that the ion exchange unit can routinely achieve a 98.5 percent yield with the 2-column system, based on 90 percent of the feed being oxalate supemates and no greater than 10 percent (on a plutonium basis) being miscellaneous solutions, 1.e., rag leaches, spent resin leaches, analytical laboratory wastes, $\mathrm{PuO}_{3}$ dissolver clean-out muns, and other similar solutions.

b. Teflon-Lined Dissolver Tests

Studies were continued in the hood 42 teflon-lined batch dissolvers used for dissolving plutonium oxide powders. The purpose of the studies is to develop a dissolver system capable of withstanding the corrosive environments (e.g., $\mathrm{HF}-\mathrm{HNO}_{3}, \mathrm{HCl}-\mathrm{HNO}_{3}$ ) required for dissolving miscellaneous materials in the reclamation facility dissolvers. Studies during the month indicated that a specially designed immersion heater would provide adequate heating and agitation in the teflon dissolvers. The initial unit was fabricated from 304-I stainless steel. Since the basic feasibility of the heater has been demonstrated, new heaters of more corrosionresistant materials are being procured.

c. Recuplex Deactivation

Removal of plutonium-bearing solids from the $\mathrm{J}-26-\mathrm{A}$ evaporator continued throughout the month. The solids have been successfully dissolved by $\mathrm{HCl}$ and $\mathrm{HF}-\mathrm{HNO}_{3}$ dissolution. To date, approximately $8 \mathrm{kgs}$ of plutonium have been removed from the evaporator. The solids in $\mathrm{J}-26-\mathrm{A}$ have been analyzed and range from $25-100$ percent plutonium sulfate. The density of the caked solids in $\mathrm{J}-26-\mathrm{A}$ is extremely high, in excess of 3.0. Based upon new neutron counter standards for the high density plutonium sulfate, it is estimated that between 2 to $4 \mathrm{kgs}$ of plutonium remain in the $\mathrm{J}-26-\mathrm{A}$ evaporaton.

A report entitled "Program for Emptying Recuplex Tanks and Flushing the Facility" has been prepared and accepted as a basis for future deactivation activities. The document presents methods for safely emptying the solutions from the various Recuplex vessels and recovering most of the plutonium from them. Also, it provides a method for flushing and clean-out of the process vessels and inner hood environment to acceptably low plutonium levels for subsequent removal operations.

\section{d. Spent Resin Leaching}

The anomalies that existed between analytical results and the neutron counter checks concerning p'.utonium left in the ion exchange resins have been clarified. Correcting for americium 
analytically and establishing a standard for the neutron counter gave results that checked within \pm 25 percent. Elutions of spent resin, using a hot water spray-wash system have reduced the plutonium left in the resin from original values as high as $25 \mathrm{~g} / \mathrm{l}$ to acceptable discard concentrations (less than $1.0 \mathrm{~g} \mathrm{Pu} / \mathrm{I}$ ).

e. Chloride Removal Process

The chloride from dissolved J-26-A (Recuplex evaporator) solidis has been successfully removed by the tri-oxalate precipitation process using laborator equipment. Waste losses previously repoxted as less than 0.5 percent were found to be less than 0.2 percent after a double precipitation process and correcting for americium present. 


\section{Separations Chemistry Laboratory}

a. Purex Process Improvement

In an effort to reduce the amount of activity being routed to the crib in the AAD stream ( $F-5$ condensates), a laboratory test was made using the AAD as ICX. The AAD increased the amount of radioruthenium in the ICO by a factor of 13 precluding its use as ICX.

b. Redox Process Improvement

Methods for Preparing Diban

Possible methods for the preparation of diban (dibasic aluminum ritrate) on plant have been investigated.

Dibasic aluminum nitrate, $\mathrm{Al}(\mathrm{OH}) \mathrm{NO}_{3}$, is a compound in which the nitrate ions do not satisfy the sum of all the charges of the aluminum ions. Solutions of diban may be termed "acid deficient," with two moles of acid deficiency for each mole of aluminum constituting stoichionetric diban. Commercial solutions of diban received at Hanford have not exceeded 1.8 moles of acid deficiency per mole of aluminum.

of the methods investigated, two appear to be most feasible: (I) acid boil-off from aluminum nitrate solutions, (2) mercury catalyzed dissolution of aluminum metal in aluminum nitrate solution.

The acid boil-off method consists of boiling $100 \%$ alminum nitrate nona-hydrate with continuous addition of water equal to the volume of distillate. Rates of acid boil-off are such that one mole of acid deficiency per mole of aluminum is readily achieved with up to 1.8 moles being a question of economics. This method jields the highest purity solution of the methods tested.

Mercury catalyzed dissolution of aluminum metal is easily accomplished with the solution purity dependent on the purity of the metal. A proposal to utilize scrap aluminum ( $x-8011$ nickel alloy) from the canning operation proved unsuccessful due to the gross amount of oxides formed and the slow rate of dissolution.

c. Fission Product Process Improvement

The oxidation of cerium with permanganate and the subsequent extraction of $\mathrm{Ce}$ (IV) into D2EHPA was tested in the laboratory usj.ng $\mathrm{z}$ synthetic HAF spiked I to 100 with Semiworiks HAF. Potassiwi Fomenganate was added in five 0.01 mole increments over a 50 minute extraction period. Ninety to 95 per cent of the cerium was extracted into laboratory solvent while only 70 per cent was extracted into Semiworks solvent.

The poor extraction exper.e lced with permanganate oxidized cerium in the Semiworks prompted a renewed search for an alternate oxidizing

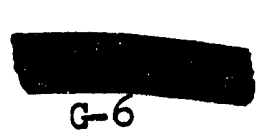


agent. Sodium bismuthate at a concentration greater than $0.04 \mathrm{M}$ and a mixture of $0.02 \mathrm{M} \mathrm{PbO}_{2}$ and $0.02 \mathrm{M} \mathrm{KMnO}_{4}$ both showed excellent oxidation and extraction characteristics for cerium on a lab scale.

\section{d. Laboratory Improvement}

A spectrophotometric method for calcium has been developed based on the color developed by a Fluorexone* complex. Calcium in the 10-100 microgram range can be determined with a standard deviation of $\pm 18 \%$ by measuring absorption at the $219 \mathrm{~mm}$ peak. A procedure to permit the separation of strontiun from calcium is being evaluated for use with this method.

Laboratory evaluation of three strong base ion-exchange resins (IRA-401, Permutit SK, Dowex-1 $\times 4$ ) was successful in recovering only 30 to $40 \%$ of the technetium present in a decalso waste solution. Technetium breakthrough was experienced early in the extraction and continued at $a$ high rate throughout the extraction of 10 column volumes of feed. Work on this problem is continuing.

* Trade Name 


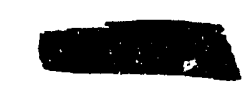

HW- 78076

\section{Plutonium Chemistry Laboratory}

\section{a. Electrowinning of Plutonium Metal}

Substitution of $\mathrm{NaCl}-\mathrm{KCl}$ for $\mathrm{IICl}-\mathrm{KCl}$ gave less melt volatilization, but resulted in lower efficiency. Plutonium oxide was used as a cell feed in a run at 65 grams of plutonium per hour in a seven hour run, witin a cathode current efficiency of 62 percent.

Use of $\mathrm{NaCl}-\mathrm{KCl}$ melt resulted in a loss of only about 20 grams of melt by volatilization, but gave a catinode current efficiency of 66 percent. Comparable runs, made at instantaneous rates of 400 grams per hour nay volatilize as much as 200 grams of melt in a normal run ( 4 hours), but give efficiencies of about 80 percent. This volatilization creates an additional recovery problen and complicates off-gas handing. Anotiner possiblilty for limiting melt volatilization may be to decrease the operating temperature (currentIy $950 \mathrm{C}$ ).

The oxide run was seven hours in duration. Pure oxide was fed to the chloride melt, which was continuously sparged with chlorine. The oxide feed rate was 65 grams of plutonium per hour, in contrast to the sustalned chloride feed rate for tinis cell of 300 grams of plutoniun per hour. The catinode current efficiency was 62 percent, assuming trat a trivalent form of plutonium vas being won. The only operating problem was due to melt volatilization wich was worse than for norual runs. Although it is felt that higher rates of oxide processing could be attained in this cell, more development would be required to obtain satisfactory production rates.

\section{b. Chloride Waste Recovery}

A surmary of avallable processes to convert chloride-bearing rastes to forms acceptable for nitrate processine has been prepared. A boil-off process is being recommended. Io further laboratory vorle is planned on this problen at the present time.

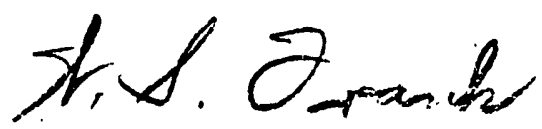

Menazer

Researci and Engineering

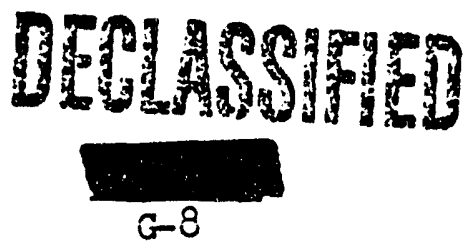


CHEMICAL PROCESSING DEPARTMENI

MONTHLY REPORT

$$
\text { JUNE, } 1963
$$

II. ACHIEVEMENIS (Conitinlied)

\section{H. FINANCIAI OPERATION}

1. Production Cost Accounting

The following adjustments were made to give effect to the 4 th Allocation of Funds, FI 1963 and to insure maximum use of funds: (1) $\$ 350,000$ of 02 Production amounts were relinquished primarily to fund IPD inventery overruns and (2) $\$ 50,000$ of 02 R\&D funds were transferred to IPD to cover year end biling rate adjustments and other needs.

The FY 1964 operating budget was adjusted to reflect the charging of CPD Finance project work to CPD overnead rather than to Indirect Construction Expense. The latter accourt was discontinued as of July I in connection with the direst contracting of Arshitect Engineer services with Vitro Corporation.

Routine work orders and expense codes were reviewea and changes made. Inciuding a complete revisicn of Purex " $E$ " codes to enable better reporting and to satisfy data processing requirements in mantpulating data.

A coding system was developed for the segregation of costs between the two weapons models.

Physical inventorles of chemicals In ail piants were observed at the erd of Jurie.

Speclai requests processed durirg the mosth inciuded (I) $30 \mathrm{Kg}^{\prime} \mathrm{s}$ unclasslfled $\mathrm{Pu}$ as rods to Savanrah River, (2) quotation on $4 C \mathrm{Kg}$ 's Pu ritrate for NUMEC, (3) $2.24 \mathrm{Kg} " \mathrm{z}$ uriclassifled $\mathrm{Pu}$ metal to cermany ard (4) 100 grams of ar:iassifled Pu metal to Switzerland.

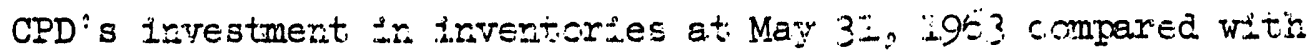
budgeted amcurts is as fo:"zins:

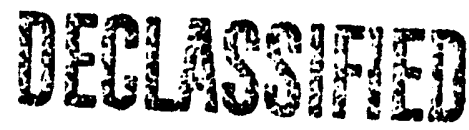

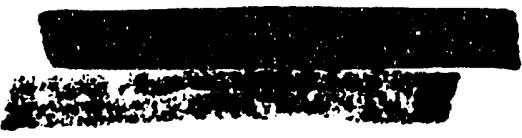


(in thousands)

Inventorles

Essential Materials

Spare Parts \& Standby

Special Materials

Gross Inventories

Reserves

Essential Materials

Spare Parts \& Standby

Total Reserves

Net Investment

\begin{tabular}{|c|c|c|}
\hline $\begin{array}{l}\text { Balance } \\
5-31-63 \\
\end{array}$ & $\begin{array}{c}\text { Control } \\
\text { Allocation } \\
\end{array}$ & $\begin{array}{l}\text { Surplus } \\
\text { (Defic1t }\end{array}$ \\
\hline $\begin{array}{r}\$ 14 \\
1724 \\
78 \\
\end{array}$ & $\begin{array}{r}825 \\
1600 \\
103 \\
\end{array}$ & $\begin{array}{c}\$ 11 \\
(124) \\
25 \\
\end{array}$ \\
\hline 2616 & 2528 & $(88)$ \\
\hline $\begin{array}{r}61 \\
550 \\
\end{array}$ & $\begin{array}{r}58 \\
481 \\
\end{array}$ & $\begin{array}{r}3 \\
69 \\
\end{array}$ \\
\hline 611 & 539 & 72 \\
\hline$\$ 2005$ & $\$ 1989$ & $\$(16)$ \\
\hline
\end{tabular}

The control allocation does not reflect the FY 1963 Fourth Allocation of Funds. Thls revision Increases total combined net inventory balances of Essentlal Materials, Spare Parts and Fabrication Work in Progress by $\$ 85,000$ resulting in a surplus of funds at May 31 , 1963 of $\$ 44,000$.

2. Personnel Accounting

Service dates were adjusted for three employees of which two were returnees from educational leaves of absence.

3. General Accounting*

As of May 31, 1963, seventeen active projects had Incurred costs of $\$ 4,485,569$ against authorized funds of $\$ 5,754,200$. Outstanding conmitments totaled $\$ 363,030$.

During May two work authorizations were recelved from the AFC as follows: Directive HW-548, Work Author1ty No. 1, establishing AEC management and decrease in funds to $\$ 16,500$ on Project CAC-981, Fission Product Packaging Facllity - B Plant; Direct1ve No. AEC-219, Work Authority No. 1 authorlzed $\$ 205,000$ to perform procurement and technical guidance of the Architect-Englneer on Project CAC-987, Metal Stabilization Facility - 234-5 Building.

Construction Completion and Cost Closing Statements were issued during June on the following projects:

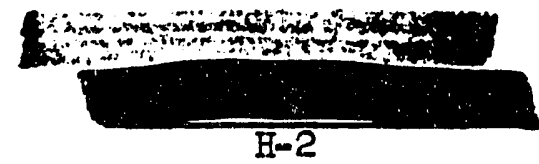


Project Number

CGC-897

CAC-928

CGC-930

CGC-948

CAC-950
Project Title

F1ssion Product Concentrates Storage Facility - 200-E

Leak Detection-High Level Waste Tanks 24I-A and 24I-SX

Secondary Containment of Dissolver Off Geses - Purex \& Redox Strontium Storage and Waste Disposal

- Hot Semiworks

Cesium Load-out Fac1lity
Total Cost

$\$ 1399636$

71. 655

262298

161816

44613

* Funding approvals cnly. May differ from costs stated in other sections of this report which include nonfund equipment transfers.

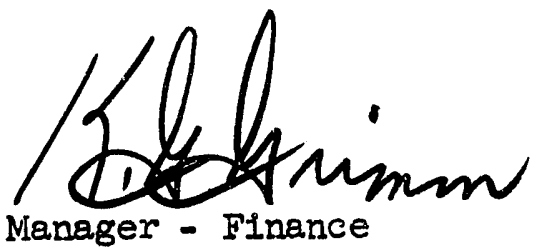




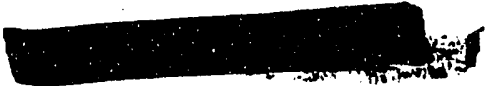

घW. 78076

CHEMICAL PROCESSING DEPARTMEANT

MONTHIY RFPORT

JUNE, 1963

III. PERSONNEI ACTIVITTHS

A. FORCE STMMARI

Monthly Salarled Weekly Salarled Trial

Operation

$5-26-63$ 6-30-63 5-26-63 6-30-63 5-26-63 6-30-63

Genera 1 Manager's Group

$11 \quad 11$

2

2

13

13

Financial

13

14

15

15

28

29

Research \& Engineering

63

63

$28 \quad 30$

92

93

Fasoulities Engineering

63

$24 \quad 26$

87

90

Power \& Crapts Operation

$38 \quad 38$

$234 \quad 237$

272

275

Production

$6 \quad 6$

44

10

10

Redox

$58 \quad 58$

$232 \quad 232$

290

290

Purex

66

70

$262 \quad 266$

328

336

Weapons Manufasturing

$49 \quad 50$

$218 \quad 222$

$267 \quad 272$

Tota 2

36

374

101

1386

1408 
C. TRIPS

\section{Visitor}

To

Nature of Discussion

To Other G.E. Components

W. S. Frank

New York, New York

G. C. Oberg

P.R。 McMurray

R. E。 Smith

Cincinnati, Ohio

Manufacturing Services

Schenectady, New York

TO AEC and Other AEC Contractors

G. C. Oberg

H. L. Brandt

R. A. Ciccarelli

P. R。 McMurray

R. E. Smith

To General Industry

D. R. Giblett

P. S. Kingsley

R. A. Kennedy
Union Carbide Nuclear Co. Oak Ridge, Tennessee

Oak Ridge National Lab.

Oak Ridge, Tennessee

Brookhaven National Lab. Upton, New York

Argonne National Lab. Lemont, Illinois

Oak Ridge National Lab. Oak Ridge, Tennessee
Northwest Copper Co. Portland, Oregon

Heyster Company

Portland, Oregon

Automatic Welders

Portland, Oregon

Coates Electric Seattle, Washington
Attend Managers' Engineering, Laboratories meeting. $(6 / 11 / 63)$

Attend Laser Symposium and conduct discussions on $0-3$ Hanford sponsored programs with $\mathrm{Mfg}$. Services personnel. $(6 / 18-20 / 63)$

Engineering consultation. $(6 / 26-27 / 63)$
Discuss hydroformed parts. $(6 / 21 / 63)$

Discuss fluidized bed reactors and technology。

$$
(6 / 24-25 / 63)
$$

Ditto above.

$(6 / 26 / 63)$

Ditto above. $(6 / 27-28 / 63)$

Attend Symposium on Isotopic Power Fuels。 $(6 / 24-25 / 63)$
Equipment for the Pu Reclamation Facility。 $(6 / 9 / 63)$

Procure sample welds 。 $(6 / 26-27 / 63)$

Procure sample welds 。 $(6 / 26-27 / 63)$

Proposed design changes 。 $(6 / 30-7 / 1 / 63)$

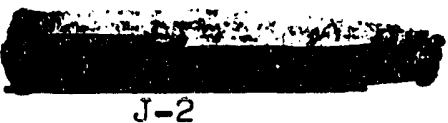


C. IRIPS (Continued)

Visitor

To

Nature of Discussion

To Conventions and General Meetings

M. H. Campbell

Bellingham, Washington

Present paper and attend

$R$. J. Sorenson

American Chemical Society meeting.

$(6 / 26-18 / 63)$

D. VISITORS

Visitor

From

Nature of Discussion

From Other G。E. Components

G. Street

Vallecitos Atomic Lab. Pleasanton, Calif。

R。J。Skilton

APED

San Jose, Calif。

Recovery and potential use of by-products.

$(6 / 11 / 63)$

Log scintillation gamma monitor。

$(6 / 18 / 63)$

From AEC and Other AEC Contractors

E。A。Stisser

D。A。Williams

W. H。 Johnson

M。 Caulkins)

I。 Killian)

W. Miller )

$R$ 。 M。Bristor

Lawrence Walker

P。C。Nosler

$\mathrm{K}$ 。 L。Swinth

A, Bo Mercer

E。B。Tremmel
Lawrence Radiation Lab。 Livermore, Calif。

LRL, Livermore, Calif。 Albuquerque Oper. Office Albuquerque, New Mexico

U.S。AEC

Washington, D。C。

Albuquerque Oper. Office Albuquerque, New Mexico

U.S。AEC

Germantown

U.S. AEC

Germantown
Reviewing gage capability and process. $(6 / 6 / 63)$

Fabrication consultation and conduct Nuclear Matl。 Quality Assurance Survey。 $(6 / 10-12 / 63)$

Plant Tour。 $(6 / 11 / 63)$

To tour facilities。 $(6 / 13 / 63)$

T-Plant crane demonstration。

$(6 / 19 / 63)$

Inspection of U-canyon and crane and Redox facilities 。

$(6 / 28 / 63)$ 
D. VISITORS (Continued)

Visitor

From

Nature of Discussion

From AEC and Other AEC Contractors (Continued)

J.F. Frost

Dow Chemical Company

E. E. Strom

Rocky Flats Plant

Denver, Colorado

Clark Williams Brookhaven National Lab. Upton, New York

\section{From General Industry}

Robert Brauer

P. Berner

W. Lindsly

R. G. Kenney

J. J. Morris

J. E. Lynch

F. W. Webking

T. F。 D'Muhala

W. E。 Beall

M. H. Gallaher

R. C. Schall
Calif. Metal Enameling Co. Seattle, Washington

Star Machine Co.

Seattle, Washington

Lodge \& Shipley Machine Co. Los Angeles, Calif.

Carborundum Company

Seattle, Washington

Precision Engineering Co. Seattle, Washington

Nalco Chemical Company

Portland, Oregon

General Dynamics Corp. Groton, Connecticut

Boeing Company

Seattle, Washington

13th Naval District

Seattle, Washington

W. P. Keith Company

Pico Rivera, California
Discuss purity metal foundry operation.

$$
(6 / 24-26 / 63)
$$

Purex and waste management processes .

$(6 / 28 / 63)$
Discuss metal sign procurement. $(6 / 10 / 63)$

Supervise installation of new machine tools.

$(6 / 11-13 / 63)$

Ditto above.

$(6 / 11-13 / 63)$

Consultations on abrasives and Vacu-blast equipment. $(6 / 20 / 63)$

Ditto above. $(6 / 20 / 63)$

Discuss water treatment. $(6 / 27 / 63)$

Decontamination chemicals and waste handling.

$$
(6 / 27 / 63)
$$

Inspection of U-canyon and crane and Redox facilities. $(6 / 28 / 63)$

Discuss mutual welding problems.

$(6 / 28 / 63)$

Repair furnace purchased from W. P. Keith Company. 


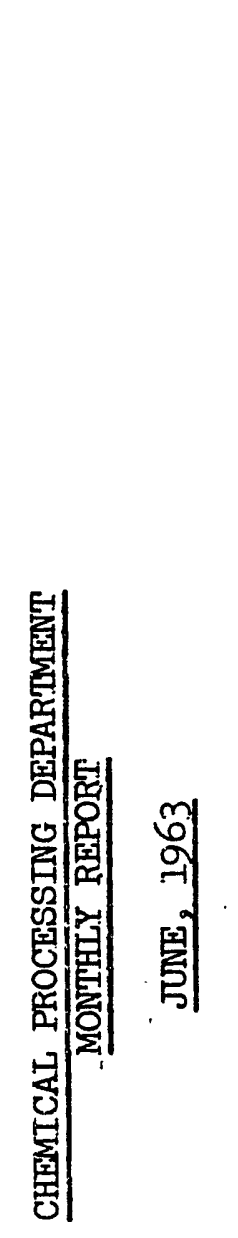

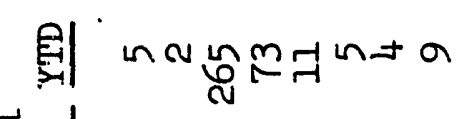

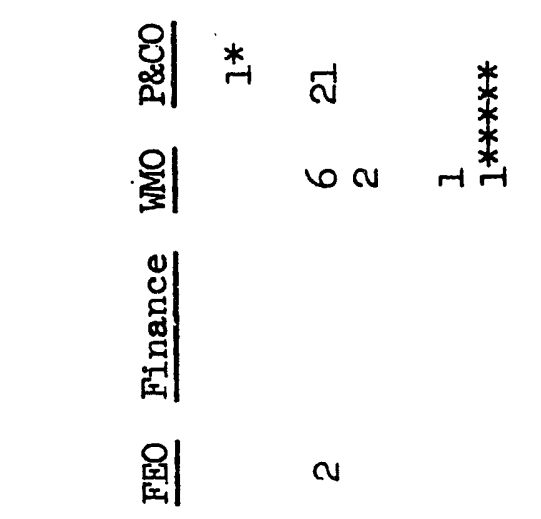

至

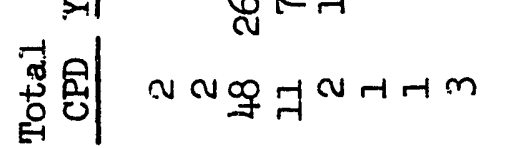
国 $m$

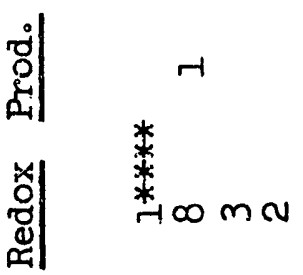

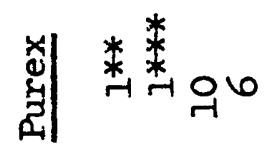

离

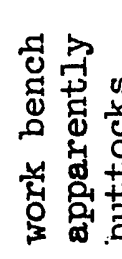

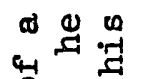

०ै हैं

总要

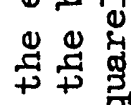

ธี 동

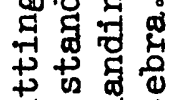

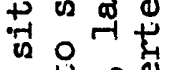

की

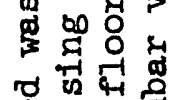

गु记

दू

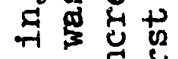

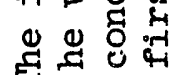

这峦

官这岁

बें

व,

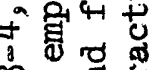

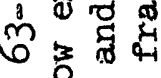

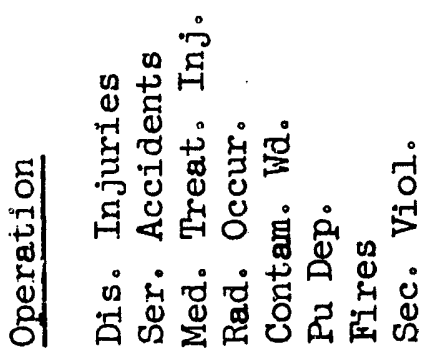

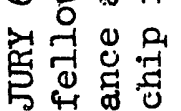

声 尔

ए

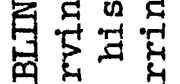

㝴要

ํㅗㅂ용

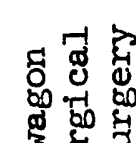

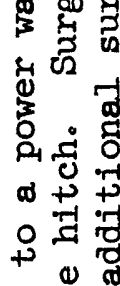

本过

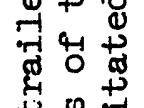

क 至

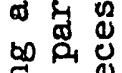

겅

号尔告

.

叫

驱芯

告

भा न

总总

की

กำ

월

ऽั

กิ

ڤึ)

宏告

若要

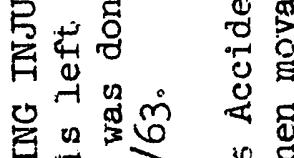

몽

象喿

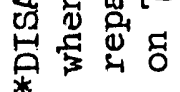

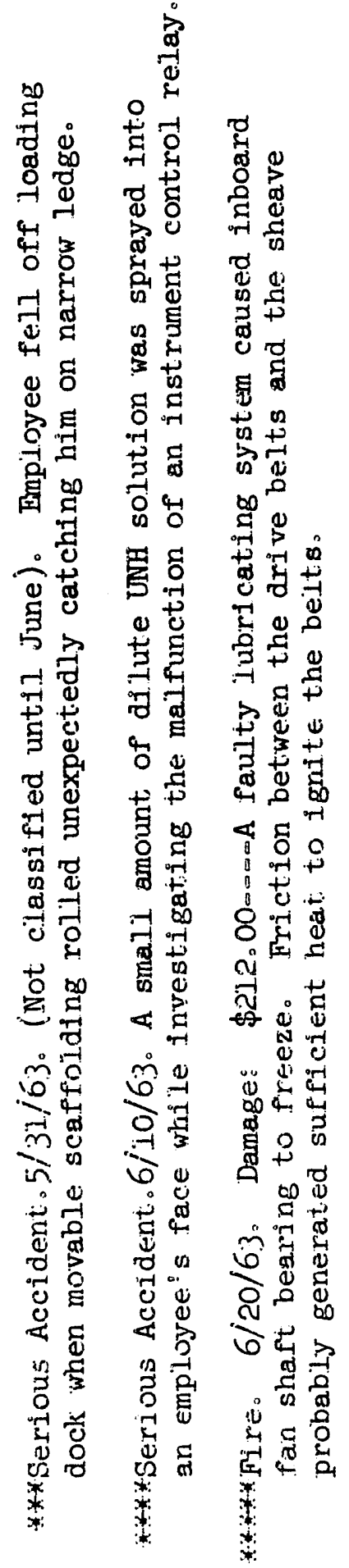

DELLAPIFED 
CHEMICAL PROCESSING DEPARTMENT

MONTHLY REPORT

JUNE, 1963

\section{V。 REPORTS}

\section{A. PREPARED AND ISSUED}

HW-76782, Official Use Only, "Project Proposal, New Standards Laboratory ' $\mathrm{Z}$ ' Plant (Project CAC-102)", dated April 26, 1963, by M。N。 Raile。

HW-77063, Official Use Only, "Project Proposal, Recoverable Plutonium Partitioning Facilities - 236-Z Building (Project CAC-104)", dated June 6, 1963, by L.W. Finch。

HW-77369, Unclassified, "Plutonium Recovery by the Quick-Leach Process", dated April 26, 1963, by M。H。Curtis 。

HW-77591, Confidential, "Screening Tests for Proposed Molten Salt Electrolytes", dated May 10, 1963, by C。R。Becker and T。S。Soine。

HW-77711, Official Use Only, "Project Proposal, Revision \#4 - Plutonium Reclamation Facility - 'Z' Plant (Project CAC-880)", dated June 7, 1963, by L. W. Finch。

HW-77739, Unclassified, "Development Report, Prototype Six-Decade Logarithmic, Scintillation Gamma Monitor", dated May 27, 1963, by $F$. S. Stong。

HW-77753, Unclassified, "Design and Performance Criteria for a SixDecade Scintillation Gamma Monitor", dated May 28, 1963, by F。S.Stong。

HW-77755, Secret AWD, "Progress Report - Weapons Process Engineering May, 1963", dated June 5, 1963, compiled by members of the Weapons Process Engineering Operation.

HW-77790 RD, Secret, "Purex Plant Production Schedule - June 1963", dated June 5, 1963, by D。 McDonald.

HW-77791 RD, Secret, "Redox Plant Production Schedule - June 1963", dated June 5,1963 , by D. McDonald。

HW-77792 RD, Secret, "UO 3 Plant Production Schedule - June 1963", dated June 5,1963 , by D。 McDonald.

HW-77793 RD, Secret, "234-5 Plant Production Schedule - June 1963", dated June 5,1963 , by D。 McDonald. 
HW-77807, Confidential, "Critical Mass Control Specification - General Specification - Pu240 Concentration", dated June 10, 1963, by R。 J。 Sloat。

HW-77823, Secret, "Exceeding Always Safe Ratio in F-2 and F-1 Tanks, Redox Processing, Redox Operation", dated June 6, 1963, by H。 P。 Simonds.

HW-77828, Unclassified, "Chemical Analyses of In-Tank Water Leach of TK-24l-A-103 Sludge as a Function of Time", dated June 6, 1963, by T。R。McKenzie。

HW-77841, Secret, "Plutonium Fabrication and Assembly Study", dated June 17, 1963, by W。 Jo Gartin。

HW-77844 RD, Confidential, "Trip Report: May 14-May 24, 1963", dated June 10, 1963, by H。H.Hopkins, Jr。 and T。S。 Soine.

HW-77877 RD, Secret, "Np Schedule - FY 1964", dated June 12, 1963, by V。 R。 Chapman。

HW-77941, Secret, "Analysis of Brandy Batch Purex Nos。 1 and 2", dated June 18, 1963, by J。H. Warren.

HW-77947, Secret AWD, "Inspection Method for Tsetse Components", dated June 21, 1963, by L。 L。 McGregor.

HW-77962, Unclassified, "Drop Test of Unbuffered $1 / 4$ Size Model HAPO-IB Cask", dated June 25, 1963, by C.W.Smith。(Rough Draft)

HW-77963, Unclassified, "Model Studies of Buffered Shipping Containers for Fission Products", dated May, 1963, by E。A。Ripperger。

HW-77981, Confidential, "Scheduled Shutdown - Uranium Oxide and Purex Plants", dated June 20,$1 ; 53$, by $\mathrm{J}$. H. Warren。

HW-77984, Secret, "Waste Tank Fill Program", dated June 20, 1963, by R。E。 Isaacson。

HW-77987, Confidential AWD, "I807 Crack-Type Defects", dated June 6, 1963, by R。 J。 Dal Ponte。

HW-77993, Secret AWD, "MC-1807 Engineering and Gage Review", dated June 21, 1963, by A。E。Smith。

HW-78003, Secret, "Analysis of Plutonium Samples (No.XXIX) on Interplant Exchange Program", dated Tune 21, 1963, by 0 , F。Beaulieu.

HW-78006, Confidential, "Limit Gaging and Special Inspection Fixture Approval", dated June 24, 1963, by A。E。 Smith。

HW-78064 RD, Secret, "IPD Discharges - June through August, 1963", dated June 27,1963 , by $\mathrm{J}$. H。 Warren。

HWS-8250, Unclassified, "Specification for Procurement of a 100,000 psi Isostatic Pressing System - 234-5 Building - 200-W Area", dated June 17,1963 , by $D$ 。 D。Wodrich。

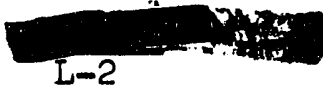


B. PREPARED FOR SIGNATURE AND ISSUANCE

HW-77794, Secret, "Prouluction - May 1963", dated June 3, 1963, by W. E. Johnson. 


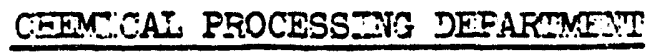

MONITEI REPORT

JNNE, 2963

\section{PATENT SUMAAFY}

All persers engaged in work that magt reasonab.y be excected to resuit in inventions or discoverses advise that, to the best of the Ir bnowledge end beisef, co irventiocs or inscovertes were made in the course of..their work during the fertod corered by thla refort, except as issted below. Suck persocs further advise that, for the pertod thersin covered by this report, noteksok records, if acy, kept in the course of their work kave been exomired for pcssible inventions or discoveries.

INVEVTOR

M. D. Sifor"d, Purex Oreration

\section{TITIF:}

Fisston Product Shipping Cask Loading Equirment
H. H. Peindin

Gererai Manager

Chems:ai Procezsing Department

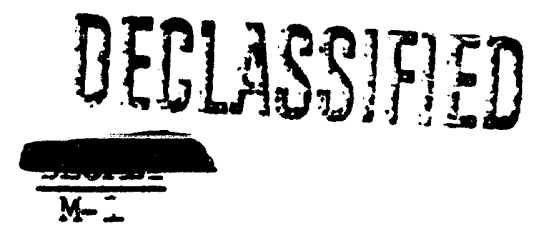



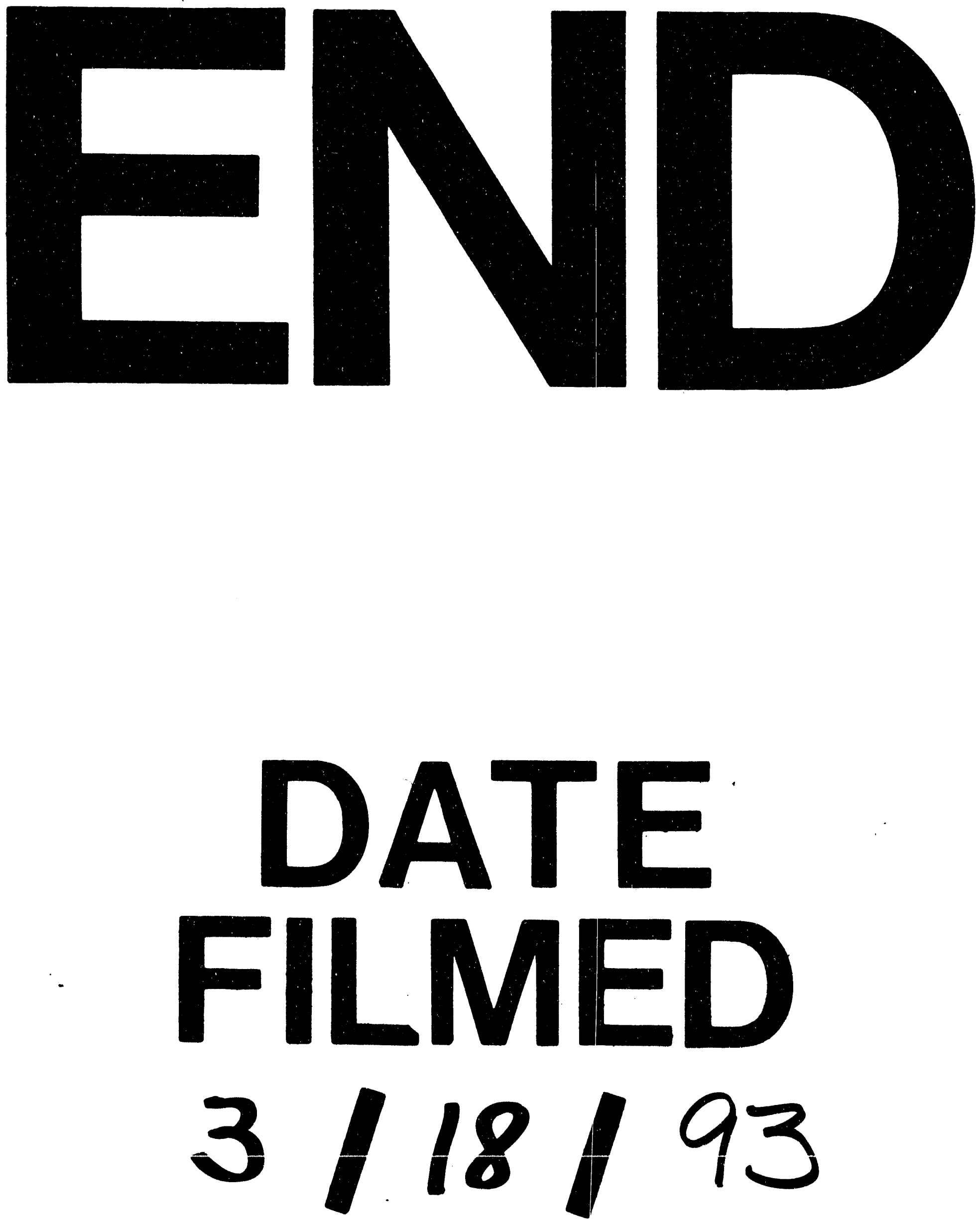

1 
